\title{
Polyploidy in Fruit Tree Crops of the Genus Annona (Annonaceae)
}

\author{
Carolina Martin†, Maria. A. Viruel, Jorge Lora and José I. Hormaza* \\ Instituto de Hortofruticultura Subtropical y Mediterránea La Mayora (IHSM-UMA-CSIC), Málaga, Spain
}

Genome duplication or polyploidy is one of the main factors of speciation in plants. It is especially frequent in hybrids and very valuable in many crops. The genus Annona belongs to the Annonaceae, a family that includes several fruit tree crops, such as cherimoya (Annona cherimola), sugar apple (Annona squamosa), their hybrid atemoya (A. cherimola $\times A$. squamosa) or pawpaw (Asimina triloba). In this work, genome content was evaluated in several Annona species, A. triloba and atemoya. Surprisingly, while the hybrid atemoya has been reported as diploid, flow cytometry analysis of a progeny obtained from an interspecific cross between $A$. cherimola and $A$. squamosa showed an

OPEN ACCESS

Edited by:

Emidio Albertini,

University of Perugia, Italy

Reviewed by:

Richard M. K. Saunders,

The University of Hong Kong,

Hong Kong

Michael David Pirie,

Johannes Gutenberg University

Mainz, Germany

*Correspondence:

José l. Hormaza

ihormaza@eelm.csic.es

${ }^{\dagger}$ Present address:

Carolina Martin,

Rijk Zwaan Ibérica S.A., Almería,

Spain

Specialty section:

This article was submitted to

Plant Breeding,

a section of the journal

Frontiers in Plant Science

Received: 08 December 2018

Accepted: 22 January 2019

Published: 11 February 2019

Citation:

Martin C, Viruel MA, Lora J and Hormaza Jl (2019) Polyploidy in Fruit

Tree Crops of the Genus Annona (Annonaceae). Front. Plant Sci. 10:99.

doi: 10.3389/fpls.2019.00099 unusual ploidy variability that was also confirmed karyotype analysis. While the progeny from intraspecific crosses of $A$. cherimola showed polyploid genotypes that ranged from 2.5 to $33 \%$, the hybrid atemoyas from the interspecific cross showed $35 \%$ of triploids from a total of 186 genotypes analyzed. With the aim of understanding the possible implications of the production of non-reduced gametes, pollen performance, pollen size and frequency distribution of pollen grains was quantified in the progeny of this cross and the parents. A large polymorphism in pollen grain size was found within the interspecific progeny with higher production of unreduced pollen in triploids (38\%) than in diploids (29\%). Moreover, using PCR amplification of selected microsatellite loci, while $13.7 \%$ of the pollen grains from the diploids showed two alleles, $41.28 \%$ of the grains from the triploids amplified two alleles and $5.63 \%$ showed up to three alleles. This suggests that the larger pollen grains could correspond to diploid and, in a lower frequency, to triploid pollen. Pollen performance was also affected with lower pollen germination in the hybrid triploids than in both diploid parents. The results confirm a higher percentage of polyploids in the interspecific cross, affecting pollen grain size and pollen performance. The occurrence of unreduced gametes in A. cherimola, A. squamosa and their interspecific progeny that may result in abnormalities of ploidy such as the triploids and tetraploids observed in this study, opens an interesting opportunity to study polyploidy in Annonaceae.

Keywords: Annona, Annonaceae, karyotype, polyploidy, triploid, tetraploid, unreduced gametes

\section{INTRODUCTION}

Polyploidy is believed to be a major mechanism of adaptation and speciation, recognized as a major force in evolution (Van de Peer et al., 2017) and very valuable for crop improvement (Udall and Wendel, 2006; Mason, 2016). Polyploidy is more common in plants than in animals. It is estimated that between 30 and $70 \%$ of extant flowering plant species are polyploids 
(Bretagnolle and Thompson, 1995; Ramsey and Schemske, 1998; Otto and Whitton, 2000; Adams and Wendel, 2005) and all angiosperms are supposed to have descended from polyploidy ancestors and, consequently, would indeed be paleopolyploids (Debodt et al., 2005; Cui et al., 2006; Jaillon et al., 2007; Soltis et al., 2009; Amborella Genome Project, 2013).

Diploid species have two sets of homologous chromosomes. Each chromosome of one set may pair with a corresponding one of the other set during meiosis. Such normal meiosis produces haploid gametes. Abnormal meiosis, due to various genetic and environmental factors, can generate unreduced gametes, or gametes with the somatic chromosome number (Ahmad et al., 1984; Saini, 1997; Viccini and De Carvalho, 2002; Sun et al., 2004; Bajpai and Singh, 2006; Rezaei et al., 2010; Wang et al., 2017). Studies on polyploid evolution have revealed that the most common mechanism of polyploidy in flowering plants involve unreduced gametes (Bretagnolle and Thompson; Darlington, 1937, 1965; Harlan and deWet, 1975; deWet, 1979; Karpechenko, 2010; Kreiner et al., 2017). Different theoretical models of polyploidy have been elaborated considering that the success of tetraploids arisen by sexual polyploidization within a diploid population is influenced by the frequency with which unreduced gametes are produced by diploids (Felber, 1991; Felber and Bever, 1997; Ramsey and Schemske, 1998; Li et al., 2004). There are two main ways to produce unreduced diploid gametes in plants, as a result of first-division restitution (FDR) or second-division restitution (SDR) during meiosis (Hermsen, 1984; De Storme and Geelen, 2013). In FDR, the first meiotic division fails and, as consequence, the two chromosomes of the unreduced gamete are non-sister chromatids. In SDR, the second meiotic division fails and the two chromosomes of the unreduced gamete are sister chromatids. A third proposed mechanism has been reported as indeterminate meiotic restitution (IMR), which produces microspores with disproportionate number of chromosomes due to a restitution mechanism (Lim et al., 2001; De Storme and Geelen, 2013).

The potential role of unreduced gametes in the origin and evolution of polyploids as well as in plant breeding, has been reviewed in different plant species (Harlan and deWet, 1975; deWet, 1979; Bretagnolle and Thompson, 1995; Ramsey and Schemske, 1998; Brownfield and Kohler, 2011; Sattler et al., 2016). The use of unreduced gametes in plant breeding is an effective tool for the induction of polyploidy and variation (Bringhurst and Köhler, 1984; Negri and Veronesi, 1989; Iwanaga et al., 1991; Dewitte et al., 2009, 2010; Younis et al., 2014; Bradshaw, 2016).

The Annonaceae is the largest extant family in the earlydivergent eumagnoliid angiosperm clade (The Angiosperm Phylogeny Group et al., 2016). The Annonaceae contains over 2400 species in more than 130 genera, grouped in four subfamilies (Anaxagoreoideae, Ambavioideae, Annonoideae, and Malmeoideae) and 14 tribes (Chatrou et al., 2012), with a pantropical distribution (Couvreur et al., 2011; Chatrou et al., 2012; Guo X. et al., 2017). A limited number of species in the Annonaceae, belonging to just two genera in the tribe Annoneae of the subfamily Annonoideae [Annona L. and Asimina Adans., since Rollinia A. St.-Hil. has been included in Annona (Rainer, 2007)], produce edible fruits. Examples include cherimoya
(Annona cherimola Mill.), sugar apple (A. squamosa L.), soursop (A. muricata L.), atemoya (a hybrid between $A$. cherimola and $A$. squamosa), custard apple (A. reticulata L.), ilama (A. macroprophyllata Donn. Sm.), pond apple (A. glabra L.), or pawpaw (Asimina triloba) (Larranaga et al., 2019). Among them, cherimoya and sugar apple have been used as food source by pre-Colombian cultures in Central and South America (Popenoe, 1989). Their cultivation has continued up to the present day, with a clear niche of expansion in countries with subtropical climates. Pawpaw is a particularly interesting fruit crop in the family because, although the fruit shows an exotic tropical flavor, Asimina is the only genus of the Annonaceae adapted to cold climates (Pomper and Layne, 2010; Losada et al., 2017). In spite of the phylogenetic position among early-divergent angiosperms and promising interest as commercial crops, few studies have evaluated ploidy in the tribe Annoneae and several discrepancies have been shown among different works, mainly in the karyotype due to the presence of grouped chromosomes (Kumar and Ranadive, 1941; Asana and Adiata, 1945; Bowden, 1945; Darlington and Ammal, 1945; Bowden, 1948; Miege, 1960; Thakur and Singh, 1965, 1969; Walker, 1972; Morawetz, 1986a,b, 1988; Datta and De, 1990; Folorunso and Olorode, 2008). Most Annona species are diploid with the exception of A. glabra (Bowden, 1945, 1948; Darlington and Ammal, 1945; Miege, 1960; Thakur and Singh, 1969; Morawetz, 1986a) and A. lutescens (Morawetz, 1986a) that have been reported as tetraploid, and the previously named Rollinia genus (now included in Annona, Rainer, 2007), showing tetraploid (A. neolaurifolia and A. exsucca, Morawetz, 1986b) and hexaploid species (A. mucosa and A. pulchrinervis, Walker, 1972; Morawetz, 1986a,b). Triploid mutants have also been occasionally reported in Asimina triloba (Bowden, 1949). Interestingly, in the frame of a breeding program in Annona an unexpected high proportion of triploid genotypes was found in the progeny of an interspecific cross involving the diploid species, A. cherimola and A. squamosa (Martin, 2013). Spontaneous triploids from crosses involving diploid parents have been reported in intra- and inter-specific crosses in several genera such as Citrus (Esen and Soost, 1971), Populus (Bradshaw and Stettler, 1993), Anthoxanthum (Bretagnolle, 2001), Rhododendron (Ureshino and Miyajima, 2002), Rosa (Crespel et al., 2006), and Asparagus (Ozaki et al., 2014).

Although polyploidy is one of the main processes involved in angiosperm evolution, the mechanisms behind it have not been evaluated previously in the tribe Annoneae in which ploidy has been reported in several species. After the finding of an unexpected high number of triploids in the progeny of an interspecific $A$. cherimola $\times A$. squamosa cross, we decided to carry out a thorough study of ploidy levels in several species of the Annoneae and analyze with detail the reasons behind the production of non-reduced gametes. For that, we first studied ploidy in several Annona species (A. senegalensis, A. montana, A. glabra, A. muricata, A. emarginata, A. neosalicifolia, A. cherimola, and A. squamosa) including the hybrid atemoya $(A$. cherimola $\times A$. squamosa) and Asimina triloba. Then, we analyzed the ploidy in some backcrosses (A. cherimola $\times$ atemoya), self-crosses (atemoya $\times$ atemoya) and intraspecific crosses $(A$. cherimola $\times$ A. cherimola $)$. Finally, 
we evaluated the implications of unreduced gametes on pollen performance, pollen size and frequency distribution of pollen grains in the parents and the progeny that result in polyploidy.

\section{MATERIALS AND METHODS}

\section{Plant Material}

Adult trees of eight Annona species (A. senegalensis, A. montana, A. glabra, A. muricata, A. emarginata, A. neosalicifolia, $A$. cherimola and $A$. squamosa) including the hybrid atemoya (A. cherimola $\times$ A. squamosa) were used in these experiments. We also included Asimina triloba because Asimina is the only genus in the tribe Annoneae in which the presence of natural triploids has been shown (Bowden, 1949). All the plant material analyzed is located in an ex situ germplasm field collection at the IHSM La Mayora-CSIC-UMA, Málaga, Spain, at latitude $36^{\circ} 45^{\prime} \mathrm{N}$, longitude $4^{\circ} 4^{\prime} \mathrm{W}$ and altitude $35 \mathrm{~m}$. The progeny obtained from an interspecific cross between diploid $A$. cherimola (cv. Fino de Jete, "Fj") and A. squamosa (cv. Thai seedless, "Ts"), four backcrosses (A. cherimola $\times$ atemoya), two selfcrosses (atemoya $\times$ atemoya) and seven intraspecific crosses (A. cherimola $\times$ A. cherimola) were also analyzed (Tables 1, 2).

\section{Measure of the Relative DNA Content Using Flow Cytometry}

Flow cytometry analysis was done with the Cystain UV Precise T Kit (Sysmex, Norderstedt, Germany). Crude nuclei were extracted from young leaves using a sharp razor blade and deposited in a nuclei isolation buffer (Sysmex, Norderstedt, Germany). After chopping, the crude solution was passed through a $30 \mu \mathrm{m}$ nylon filter and mixed with staining buffer (Sysmex) in a proportion of 1 volume of crude solution to 4 volumes of staining buffer. Relative DNA content was measured by using a Cyflow ${ }^{\circledR}$ PA, Partec. DNA content was quantified relative to $2 \mathrm{C}$ DNA content from the tomato cultivar, Moneymaker (1.9 pg) (Bennett et al., 2000). The 2C value corresponds to the DNA content of a somatic diploid nucleus (Doležel et al., 1989; De Rocher et al., 1990). DNA content was based on 3000-5000 nuclei per sample and two independent replicates and was calculated using the following formula (Dolezel and Bartos, 2005): Sample 2C DNA content $=[$ (sample $\mathrm{G}_{1}$ peak mean $) /\left(\right.$ standard $\mathrm{G}_{1}$ peak mean $\left.)\right] \times$ standard $2 \mathrm{C}$ DNA content (pg DNA). DNA content (pg) was converted to mega base pairs (Mpb), 1 pg = $980 \mathrm{Mpb}$ (Bennett et al., 2000).

\section{Karyotype}

Chromosomes were observed both in flower buds and in young leaves. Flower buds were fixed and stored in 3:1 (v/v) ethanol: acetic acid. The karyotype was evaluated in somatic cells from young pistils that were hydrolyzed using $1 \mathrm{~N} \mathrm{HCl}$, incubated 30 $\mathrm{s}$ at $65^{\circ} \mathrm{C}$, and squashed in $1 \%$ aceto-carmine under a coverslip. Young leaves were hydrolyzed using $45 \%$ acetic acid, heated by flame $5 \mathrm{~s}$ and squashed. Then, the slide was introduced in liquid nitrogen for several seconds and stained with a solution of $1 \mu \mathrm{g} / \mathrm{mL}$ of $4^{\prime}, 6$-diamidino-2-phenylindole (DAPI). The methods were modified from Burley (1965), Tanaka and Okada (1972), and Leeton and Fripp (1991).

\section{DNA Analysis From Single Pollen Grains Sample Handling}

Annona cherimola and A. squamosa flowering cycles are characterized by a protogynous dichogamous system (Wester, 1910), a common characteristic in Annonaceae (Gottsberger, 1999). Dehiscent anthers from flowers at the male stage of diploid and triploid hybrids and from the two parents of the interspecific cross were shaken using forceps inside $1.5 \mathrm{ml}$ Eppendorf tubes to release the pollen grains; then the pollen grains were stored in a freezer before manipulation. Pollen grains were mixed with $30 \mu \mathrm{l}$ sterile distilled water in the $1.5 \mathrm{ml}$ Eppendorf tubes and carefully pipetted back and forth. A drop from the mixture of diluted pollen was placed in a disposable Petri dish and observed under a Leica S6D stereo microscope $(2.5 \times$ magnification $)$. Some characteristics of the pollen grain such as the rigid and thick exine (Santos and Mariath, 1999; Parre and Geitmann, 2005) and the size from 0.005 to $0.25 \mathrm{~mm}$ in diameter (Perveen and Qaiser, 2001; Sarkissian and Harder, 2001) facilitate handling and, as a consequence, the selection of individual pollen grains. However, in A. cherimola, as in other Annonaceae (Lora et al., 2009, 2014), the four sibling haploid microspores are held together in a persistent pollen mother cell wall that is surrounded by callose until its dissolution when the microspores are shed free. Because of that, the individual pollen grains had to be mechanically separated by moving them within the drop of water with the help of a single hair paintbrush to reduce static electricity.

TABLE 1 | DNA ploidy levels of Annona spp. and Asimina triloba.

\begin{tabular}{|c|c|c|c|c|}
\hline $\mathbf{N}^{\circ}$ accessions & Species & DNA content of $1 \mathrm{C}(\mathrm{pg})$ & Genome size (Mpb) & Ploidy \\
\hline 338 & Annona cherimola & 1.7 & 1666 & $2 \times$ \\
\hline 1 & Annona squamosa & 1.63 & 1597 & $2 \times$ \\
\hline 5 & A. cherimola $\times$ A. squamosa & 1.75 & 1715 & $2 \times$ \\
\hline 1 & Annona senegalensis & 1.7 & 1666 & $2 \times$ \\
\hline 1 & Annona muricata & 1.7 & 1666 & $2 \times$ \\
\hline 1 & Annona emarginata & 1.68 & 1646 & $2 \times$ \\
\hline 1 & Asimina triloba & 1.7 & 1666 & $2 \times$ \\
\hline 1 & Annona neosalicifolia & 4.82 & 4724 & $6 x$ \\
\hline
\end{tabular}


TABLE 2 | DNA ploidy levels of the progeny from interspecific and intraspecific crosses, backcrosses and self-crosses.

\begin{tabular}{|c|c|c|c|c|c|}
\hline Type of cross & Cross $\left(\circ \times \sigma^{7}\right)$ & Diploid & Triploid & Tetraploid & $n$ \\
\hline \multicolumn{6}{|l|}{ Interspecific } \\
\hline A. cherimola $\times$ A. squamosa & 'Fj'2 $\times$ 'Ts'2 & $121(65 \%)$ & $65(35 \%)$ & $0(0 \%)$ & 186 \\
\hline Backcross (F2) & 'Fj'2 $\times$ 'FT9'3 & $3(100 \%)$ & $0(0 \%)$ & $0(0 \%)$ & 3 \\
\hline \multirow[t]{3}{*}{ A. cherimola $\times$ atemoya } & 'Fj'2 x 'FT175'3 & $6(86 \%)$ & $1(14 \%)$ & $0(0 \%)$ & 7 \\
\hline & 'Fj'2 × 'FT197'3 & $17(89.5 \%)$ & $1(5.25 \%)$ & $1(5.25 \%)$ & 19 \\
\hline & & & $\bar{x}=3.4 \%$ & & \\
\hline \multicolumn{6}{|l|}{ Backcross (F3) } \\
\hline A. cherimola $\times$ atemoya & 'Campas'2 × 'FT16’4 & $0(0 \%)$ & $9(56.25 \%)$ & $7(43.75 \%)$ & 16 \\
\hline Self-cross & $' \mathrm{FT} 7{ }^{\prime 2} \times ' \mathrm{FT} 7{ }^{\prime 2}$ & $34(100 \%)$ & $0(0 \%)$ & $0(0 \%)$ & 34 \\
\hline \multirow[t]{2}{*}{ Atemoya $\times$ atemoya } & 'FT2O’2 × 'FT2O’2 & 59 (99\%) & $1(0.6 \%)$ & $0(0 \%)$ & 60 \\
\hline & & & $\bar{x}=1 \%$ & & \\
\hline Intraspecific & 'Bonita'2 × 'Fj'2 & $157(97.5 \%)$ & $4(2.5 \%)$ & $0(0 \%)$ & 161 \\
\hline \multirow[t]{7}{*}{ A. cherimola $\times A$. cherimola } & 'Fj'2 × 'Bonita'2 & $71(96 \%)$ & $3(4 \%)$ & $0(0 \%)$ & 76 \\
\hline & 'SM35'2 × 'Fj'2 & $2(67 \%)$ & $1(33 \%)$ & $0(0 \%)$ & 3 \\
\hline & $' F j ' 2 \times$ 'SM35'2 & $4(80 \%)$ & $1(20 \%)$ & $0(0 \%)$ & 5 \\
\hline & 'SP12'2 × 'Pazicas'² & $82(92.1 \%)$ & $7(7.9 \%)$ & $0(0 \%)$ & 89 \\
\hline & 'SP12’2 × 'León'2 & $84(81.2 \%)$ & $16(18.8 \%)$ & $0(0 \%)$ & 85 \\
\hline & 'León'2 × 'IX-24'2 & $84(96.6 \%)$ & $3(3.4 \%)$ & $0(0 \%)$ & 88 \\
\hline & & & $\bar{x}=6.9 \%$ & & \\
\hline
\end{tabular}

Ploidy in the parents: diploids ${ }^{2}$; triploids ${ }^{3}$; tetraploids ${ }^{4}$. Fj, Fino de Jete.

\section{DNA Extraction}

Flow cytometry and chromosome counting do not allow the determination of the parental origin of the extra haploid genome in the triploids. However, polymorphic, heterozygous and codominant markers, like microsatellites, provide an interesting tool to analyze the ploidy level and the genetic origin. This approach can even be used with single pollen grains. For the genotyping analyses, pollen grains were collected from flowers just before anther dehiscence in 15 diploid and 15 triploid hybrids from the same interspecific cross. Twenty pollen grains were isolated per genotype. After collection, individual pollen grains were transferred to a DNA-free PCR tube ( $0.2 \mathrm{ml}$ capacity) containing $2 \mu \mathrm{l}$ of extraction buffer (Isagi and Suyama, 2011): $0.01 \%$ sodium dodecyl sulfate, SDS, $0.1 \mathrm{~g} / \mathrm{l}$ proteinase $\mathrm{K}, 0.01 \mathrm{M}$ Tris-HCl pH 7.8 and 0.01 M EDTA. Following this step, the presence of a single pollen grain in the drop of buffer was checked under the stereo microscope. The DNA extract from the single pollen grain was used directly as a PCR template. The PCR tube was then closed and incubated at $37^{\circ} \mathrm{C}$ for $60 \mathrm{~min}$ and $95^{\circ} \mathrm{C}$ for $11 \mathrm{~min}$.

\section{Single Pollen Grain Genotyping}

The multiplex PCR method (Chamberlain et al., 1988) was used to amplify multiple microsatellite loci simultaneously in a single reaction. Genotypes of each pollen grain were analyzed using two microsatellite primers developed in A. squamosa LMTS52 and LMTS135 (GenBank KF010995 and KF011078, respectively). Multiplex PCR amplification was performed using a thermalcycler (Bio-Rad Laboratories, Hercules, CA, United States) under the following conditions: an initial step of activation at $94^{\circ} \mathrm{C}$ for $1 \mathrm{~min}$, then 35 cycles of denaturation at $94^{\circ} \mathrm{C}$ for $30 \mathrm{~s}$, annealing at $50^{\circ} \mathrm{C}$ for $30 \mathrm{~s}$, and extension at $72^{\circ} \mathrm{C}$ for $1 \mathrm{~min}$, followed by a final extension at $72^{\circ} \mathrm{C}$ for $5 \mathrm{~min}$. The volume of the reaction mixture was $10 \mu \mathrm{l}$ containing extracted DNA from a single pollen grain, $16 \mathrm{mM}$ of $\left(\mathrm{NH}_{4}\right) \mathrm{SO}_{4}, 67 \mathrm{mM}$ of Tris-HCL, $\mathrm{pH}$ $8.8,0.01 \%$ of Tween $20,4 \mathrm{mM}$ of $\mathrm{MgCl}_{2}, 10 \mathrm{mM}$ de $\mathrm{KCl}, 0.1 \mathrm{mM}$ of each dNTP, $2.6 \mu \mathrm{M}$ of each primer and $0.9 \mathrm{U}$ de BioTaq ${ }^{\mathrm{TM}}$ DNA polimerase (Bioline). Forward primers were labeled with a fluorescent dye on the $5^{\prime}$ end. PCR products were analyzed by capillary electrophoresis in a CEQ ${ }^{\mathrm{TM}} 8000$ genetic analyzer (Beckman Coulter, Fullerton, CA, United States).

\section{Occurrence and Frequency of $2 n$ Pollen Grains}

The identification and analysis of the frequency of unreduced microspores from diploid and triploid plants were also made by analyzing the distribution of pollen grain size. To measure pollen size, $0.05 \mathrm{~g}$ of anthers from two flowers in the male stage per genotype were placed over a microscope slide. After adding a drop of $45 \%$ acetic acid, the anthers were pressed with forceps to release the pollen grains and then the remnant of the anthers removed. Autofluorescence from the exine of the pollen grains allowed visualizing the samples without staining. Preparations were observed under an epifluorescent Leica DM LB2 microscope with a 340-380 excitation filter. Measurements of the diameters of pollen grains in both parents and the hybrids were made with the Image J software over pictures taken with a Canon Power Shot S50 camera attached to the microscope.

The diameter of a minimum of 200 pollen grains per flower was measured and the range and distribution of pollen size was calculated for each plant. The frequency of $2 n$ pollen grains was recorded by counting all the pollen grains of each sample and separating them into ranges of five units, according to their size. Following the distribution frequency of the pollen diameter, a 
threshold that corresponded to the mean size in each individual, above which the pollen grains were considered as unreduced, was established. The percentage of unreduced microspores was calculated as the accumulative frequency above the mean size diameter. Some pollen grains with irregular shapes were observed in the samples; those irregular grains, together with those poorly developed, were not considered to determine the pollen diameter. A Student's $t$-test at the 0.05 significance level was used to compare the unreduced pollen production between diploid and triploid genotypes. To detect a putative relationship between the unreduced pollen production and ploidy level, the Pearson's correlation coefficient at the 0.01 significance level was computed. Statistical analyses were performed using SPSS 17.0 statistical software (SPSS Inc., Chicago, IL, United States).

\section{Pollen Germination}

To evaluate in vitro pollen germination, pollen was maintained within the dehisced anthers as reported previously (Rosell et al., 1999); the anthers were hydrated leaving them in a glass vial placed in a covered tray with wet filter paper for $60 \mathrm{~min}$ at room temperature. Then, approximately $0.02 \mathrm{~g}$ of pollen with anthers was placed on a $35 \mathrm{~mm}$ Petri dish with 1-2 $\mathrm{ml}$ of liquid germination medium at room temperature (Lora et al., 2006, 2012). Pollen was considered as germinated when the length of the tube was longer than the grain diameter. Data were collected from four Petri dishes with at least 200 pollen grains counted in each one. The pollen germination medium consisted of $8 \%$ sucrose, $200 \mathrm{mg} / \mathrm{l} \mathrm{MgSO} 47 \mathrm{H}_{2} \mathrm{O}, 250 \mathrm{mg} / \mathrm{l} \mathrm{Ca}\left(\mathrm{NO}_{3}\right)_{2} 4 \mathrm{H}_{2} \mathrm{O}$, $100 \mathrm{mg} / \mathrm{l} \mathrm{KNO}$, and $100 \mathrm{mg} / \mathrm{l} \mathrm{H}_{3} \mathrm{BO}_{3}$ (Lora et al., 2006).

To evaluate in vivo pollen germination, pollen tube growth was documented using squash preparations of stigmas from hand pollinated flowers kept in water at room temperature. For this purpose, pistils were fixed in formalin-acetic acid-alcohol (FAA) $24 \mathrm{~h}$ after pollination and stored at room temperature. Pistils were water washed and placed in $1 \mathrm{~N} \mathrm{NaOH}$ for $1 \mathrm{~h}$ to soften the tissues. Stigmas were dissected and squash preparations were stained with $0.1 \%$ aniline blue in $\mathrm{PO}_{4} \mathrm{~K}_{3}$ (Currier, 1957; Linskens and Esser, 1957) and observed with a 340-380 nm excitation filter and an LP425 barrier filter.

\section{RESULTS}

\section{Ploidy in Annona}

To study polyploidy in the tribe Annonae, we first analyzed the ploidy and DNA content in eight Annona species and Asimina triloba (Table 1). Annona cherimola, A. squamosa, A. senegalensis, A. muricata, A. emarginata, and Asimina triloba showed a DNA content between 1.63 and $1.75 \mathrm{pg}$ that correspond to ploidy level $2 \times$. To the best of our knowledge, this is the first reported ploidy of A. senegalensis, showing diploidy, and A. neosalicifolia, which showed a higher DNA content of $4.82 \mathrm{pg}$ and, consequently, can be considered as hexaploid (Table 1).

To confirm the ploidy in the Annona species studied, we evaluated the karyotype using acetocarmine (Figure 1) and DAPI (Figure 2). The acetocarmine staining in somatic cells from young flower buds revealed all different phases of mitosis
(Figure 1). More specifically, DAPI staining revealed the number of somatic chromosomes that confirmed the abovementioned ploidy. Thus, A. cherimola, A. squamosa, the diploid atemoyas observed by flow cytometry analysis and A. muricata showed 14 somatic chromosomes (Figure 2). Additionally, we also quantified the number of chromosomes of A. glabra that was 28 (Figure 2D) confirming its $4 \times$ ploidy level (Bowden, 1948). The hexaploidy of $A$. neosalicifolia was also confirmed by its karyotype showing 42 chromosomes (Figure 2E). Thus, the karyotype and the flow cytometry analyses revealed that the basic chromosome number in Annona is seven.

\section{Polyploidy in the Interspecific Cross A. cherimola $\times$ A. squamosa}

Annona cherimola and $A$. squamosa can be intercrossed to produce the cultivated $A$. squamosa $\times A$. cherimola hybrid, atemoya. We analyzed DNA content in five accessions of atemoya and the results showed a ploidy of $2 \times$ (Table 1). To further examine ploidy in atemoya, we also studied the ploidy in 186 atemoyas of the progeny from the interspecific cross A. cherimola (cv. Fino de Jete, "Fj") $\times$ A. squamosa (Thai seedless. "Ts"). Surprisingly, the interspecific cross showed 65 triploid individuals (35\%, Table 2). Thus, additionally, we also studied the progeny from four backcrosses $(A$. cherimola $\times$ atemoya), two self-crosses (atemoya $\times$ atemoya) and seven intraspecific crosses $(A$. cherimola $\times A$. cherimola $)$. The resulting progeny showed diploid, triploid and, interestingly, tetraploid individuals (Table 2). Three of the backcrosses were performed using pollen from triploid atemoyas and triploid individuals were observed in the progeny of two of them. The fourth backcross was performed in the two directions with the tetraploid individual. No fruits were obtained when the tetraploid genotype was used as maternal parent but fruits were obtained when it was used as male parent, showing 56\% of triploids and $44 \%$ of tetraploids in the progeny. Anomalies in ploidy were also frequent in the intraspecific crosses showing $6.9 \%$ of triploid individuals and was less frequent in the self-crosses (Table 2). Consistent with the flow cytometry data, the karyotype of diploid, triploid and tetraploid atemoyas from the interspecific cross $A$. cherimola $\times$ A. squamosa showed 21 and 28 chromosomes, respectively (Figures $\mathbf{2 F}-\mathbf{H}$ ). Taken together, anomalous ploidy was more frequent in interspecific crosses than in intraspecific crosses.

\section{DNA Amplification and Genotyping From Single Pollen Grains}

Genotyping of 20 pollen grains per genotype was performed with two microsatellite markers, LMTS52 and LMTS135, which amplified two alleles in the female parent, A. cherimola "Fj" and only one in the male parent, A. squamosa "Ts."

Within each genotype, we observed pollen grains with patterns of only one peak, diallelic and triallelic patterns with different frequencies in triploids. Among the diploid interspecific hybrids analyzed, $13.7 \%$ of the pollen grains showed two alleles for the same locus. Among interspecific triploid hybrids, $41.28 \%$ of the pollen grains had two alleles and $5.63 \%$ three 

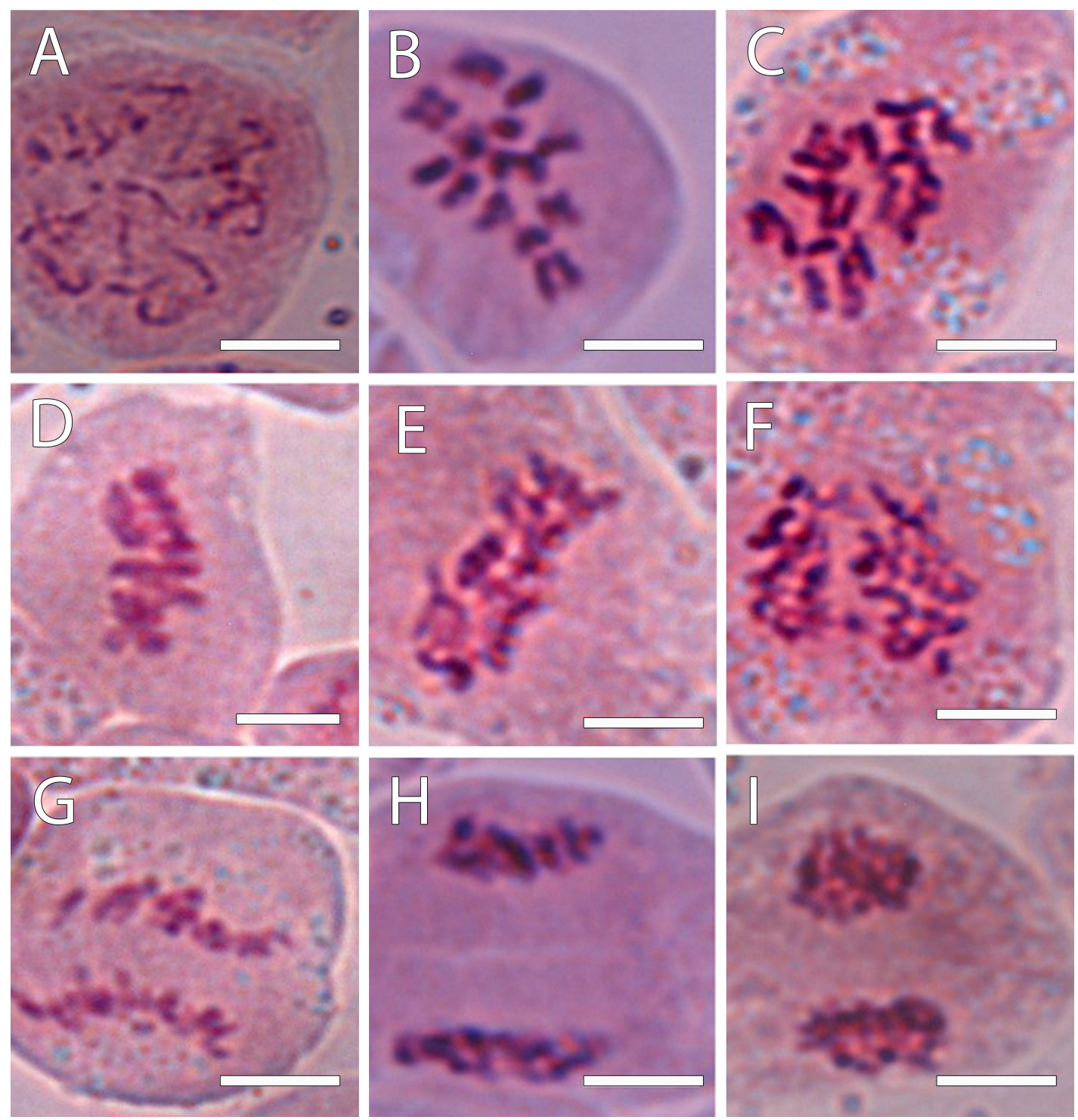

FIGURE 1 | Chromosomes revealed using $1 \%$ acetocarmine from the progeny of the interspecific cross $A$. cherimola $\times$ A. squamosa during the mitotic cycle.

(A) Chromosomes in a diploid hybrid during early prophase. (B,C) Prometaphase in a diploid (B) and triploid hybrid (C). (D,E) Metaphase in a diploid (D) and triploid hybrid (E). (F) Chromosomes in a triploid hybrid in an early anaphase. (G) Late anaphase in a diploid hybrid. (H,I) Telophase in a diploid hybrid. Scale bars, $10 \mu \mathrm{m}$.

peaks corresponding to three alleles with clear and stable amplification signals.

\section{Pollen Performance Was Affected in Triploid Hybrids}

Changes of nuclear DNA content could affect pollen performance. Thus, we next studied pollen grain size and pollen germination. Differences in size among pollen grains from the same genotype were observed in the samples analyzed in this study (Figure 3).

A high polymorphism in the size of pollen grains was detected within the interspecific progeny. Among the analyzed diploid hybrids, pollen grains with sizes ranging from 22 to $100 \mu \mathrm{m}$ were observed with an average pollen size of $52 \pm 10 \mu \mathrm{m}$. In the case of the triploid hybrids, pollen grain size ranged from 18 to $126 \mu \mathrm{m}$ with an average size of $56 \pm 11 \mu \mathrm{m}$. Regarding the closely related parental genotypes, pollen grain size ranged from 43 to $63 \mu \mathrm{m}$ with an average of $52 \pm 4 \mu \mathrm{m}$ in the female parent (A. cherimola, "Fj"), and from 33 to $58 \mu \mathrm{m}$ with an average of $44 \pm 4 \mu \mathrm{m}$ in the male parent (A. squamosa, "Ts").

We established a threshold in pollen grain size in each analyzed individual corresponding to its mean size to determine the percentage of unreduced pollen. Thus, in general, a higher proportion of unreduced pollen grains was observed in triploids $(38 \pm 9 \%)$ than in diploids $(29 \pm 10 \%)$. Moreover, we observed "giant" grains both in diploids and triploids with diameters larger than $75 \mu \mathrm{m}$. The frequency distribution of pollen size 

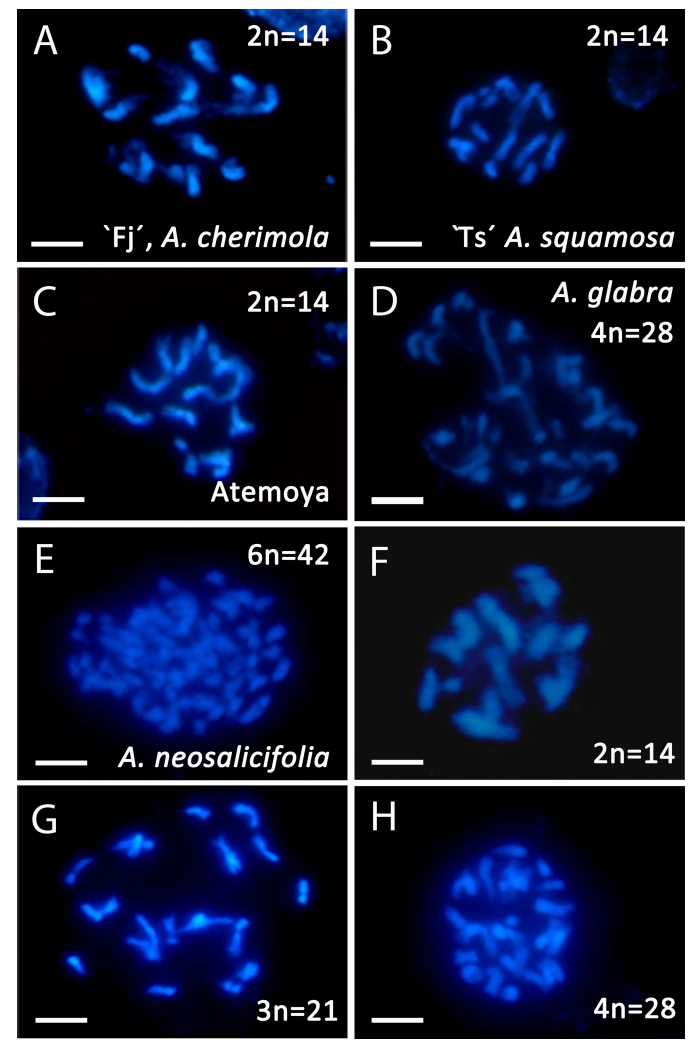

FIGURE 2 | Somatic chromosomes revealed using DAPI staining in Annona spp. (A) Diploid A. cherimola, cv. Fino de Jete, "Fj", (B) Diploid A. squamosa, Thai seedless "Ts", (C) Diploid atemoya. (D) Tetraploid A. glabra.

(E) Hexaploid A. neosalicifolia. (F,H) Diploid hybrid (F), triploid hybrid (G) and tetraploid hybrid $\mathbf{( H )}$ from the interspecific cross $A$. cherimola $\times A$. squamosa. Scale bars, $10 \mu \mathrm{m}$.

of parents and diploid and triploid progeny was clearly distinct (Figure 3). While in the parental genotypes mainly three pollen grain diameters can be distinguished (Figures 3A-D), both diploid and triploid hybrids showed an overlap in size distribution between reduced and unreduced pollen and a larger variation in the frequency distribution of pollen grain size (Figures 3E-H). The production of unreduced pollen differed statistically between diploids and triploids, $(t=-3.01, \mathrm{df}=38$, $P=0.005)$. The distribution was unimodal and symmetrical in diploids whereas it was skewed toward larger diameter values in triploids (Figure 3). A significant correlation was observed between the frequency of unreduced pollen and the ploidy level of the hybrids (Pearson's correlation coefficient $r=0.439, P=0.005$, $N=40$ ). Additionally, individual frequency distribution data revealed that some genotypes from the interspecific progeny, including diploids and triploids, are more capable of producing unreduced pollen than others.

We next evaluated if these morphological differences among pollen grains result in differences in pollen germination. Percentage of pollen germination in vitro in triploid hybrids ranged from 15 to $45 \%$ with an average of $27 \%$. By contrast, pollen germination in vitro in diploid genotypes ranged between
21 and $72 \%$ with an average of $36 \%$. Pollen germination in vitro was higher in the parental lines (75\% in "Fj" and 55\% in "Ts") compared with triploid (19\%) and diploid (36\%) hybrids. We evaluated pollen germination in vivo on the stigma using pollen from the parental line, "Fj", a triploid hybrid and a tetraploid hybrid from the backcross "Fj" $\times$ "FT197." Pollen from "Fj" showed higher germination $(58 \% \pm 3.8, n=646)$ than pollen from a triploid hybrid $(7.7 \% \pm 0.4, n=267)$. Pollen from a tetraploid hybrid also showed high germination $(49 \% \pm 10.5$, $n=419$, Figure 4).

\section{DISCUSSION}

Polyploidization is one of the main force of evolution and crop improvement in flowering plants. Although most species of the genus Annona show diploidy, the progeny of a cross between diploid $A$. cherimola and A. squamosa showed an unexpected high polyploidy level with a high number of triploid hybrids. Consequently, in order to understand the reasons of this unexpected high number of triploids, we analyze the polyploidy and its consequences for pollen performance in different species of the genus Annona and in Asimina triloba.

\section{Polyploidy in Annonaceae}

It has been suggested that the ancestral basic chromosome number in Annonaceae is seven (Walker, 1972), that has also been considered as the basic chromosome number in flowering plants (Grant, 1963). However, in the tribe Annoneae, a haploid chromosome number of seven has only been reported in the genus Annona; in this tribe, $x=8$ has been reported in the genus Asimina (Tanaka and Okada, 1972), Disepalum (Johnson, 1989), Goniothalamus (Sauer and Ehrendorfer, 1984), and Neostenanthera (Walker, 1972). Moreover, $x=8$ has also been reported in sister lineages such as the tribes Monodoreae (genera Isolona, Monodora, and Uvariopsis) (Walker, 1972) and Uvarieae (genera Dasymaschalon, Desmos, Fissistigma, Friesodielsia, Melodorum, Mitrella, Sphaerocoryne, and Uvaria) (Walker, 1972; Okada and Ueda, 1984; Sauer and Ehrendorfer, 1984; Van Heusden, 1992) and in the more basal tribes Duguetieae (genera Duguetia and Fusaea) and Xylopieae (genera Artabotrys and Xylopia) (Morawetz, 1984; Van Heusden, 1992). This could indicate that $x=7$ in Annona may have arisen by aneuploid chromosome loss from ancestors with $x=8$. Indeed, Morawetz (1986a) already proposed $x=8$ as the original basic chromosome number in Annonaceae. In this work we have observed the haploid chromosome number seven in A. cherimola, A. squamosa and their hybrid, atemoya, which supports previous karyotype reports in both species (Kumar and Ranadive, 1941; Asana and Adiata, 1945; Thakur and Singh, 1965, 1969; Tanaka and Okada, 1972; Morawetz, 1986a) in contrast to $x=8$ reported by Bowden $(1945,1948)$. The presence of the eighth chromosome could be due to the confusion of distant satellite (or whole arms) with separate chromosomes (Sauer and Ehrendorfer, 1984). Polyploidy has been reported in nine genera of the Annonaceae (Van Heusden, 1992), mainly tetraploids although triploids have also been reported in Cymbopetalum (Morawetz, 

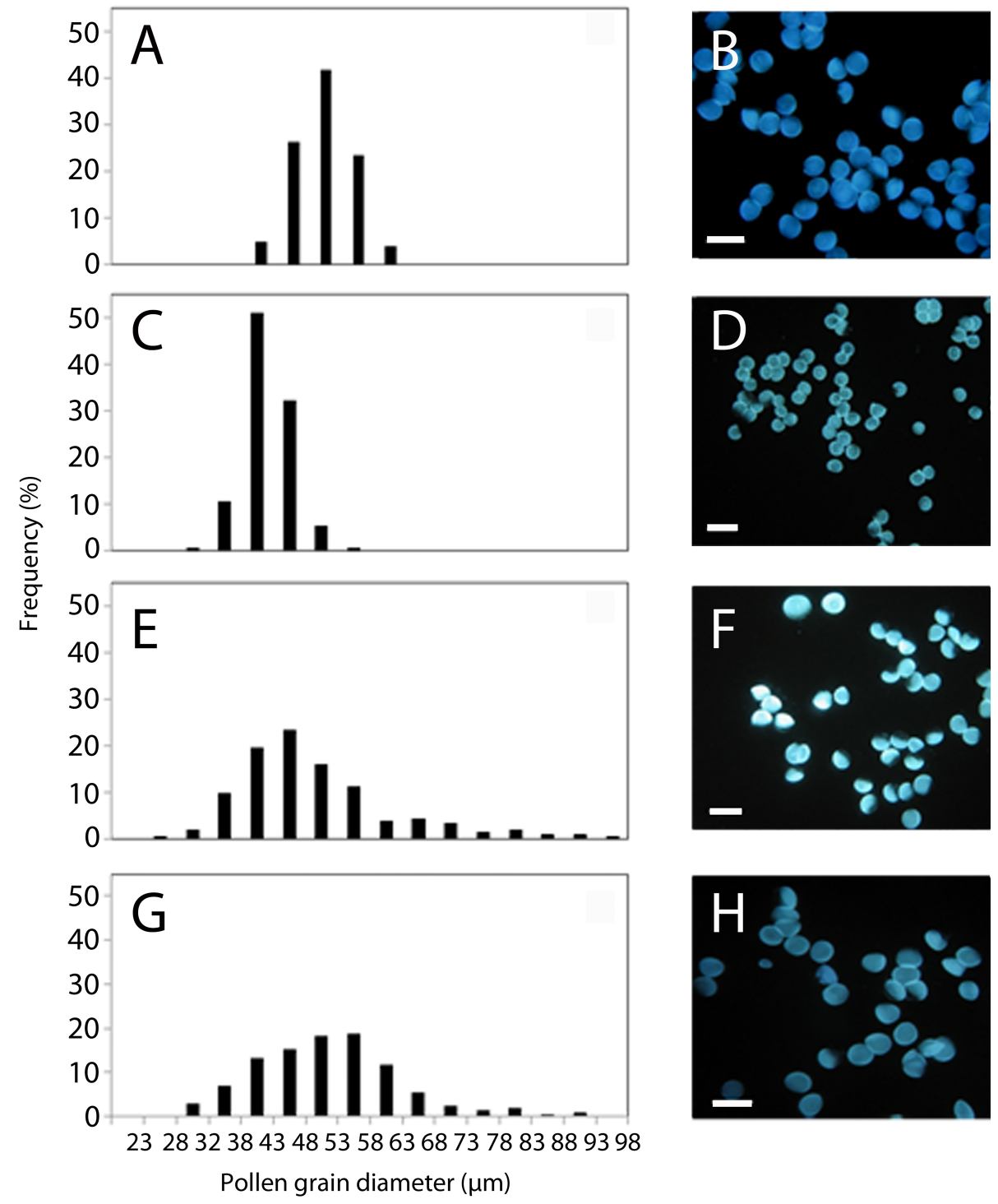

FIGURE 3 | Frequency distribution and images showing the heterogeneity of pollen diameters in the parental genotypes, Annona cherimola cV. Fino de Jete, "Fj" $\mathbf{( A , B )}$ and Annona squamosa, Thai seedless "Ts" (C,D), in the FT148 hybrid diploid (E,F) and in the FT6 hybrid triploid (G,H) from the interspecific cross between A. cherimola $\times$ A. squamosa. Scale bars, $10 \mu \mathrm{m}$.
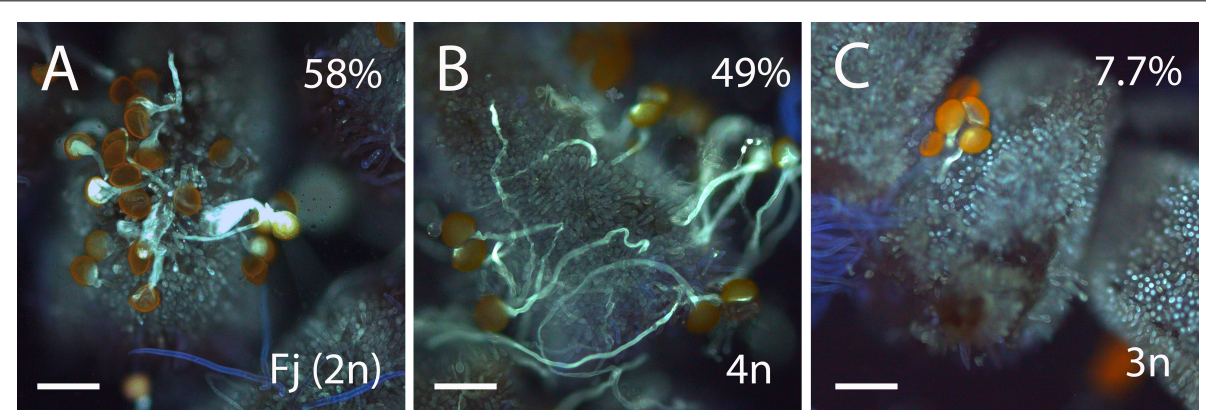

FIGURE 4 | Aniline-blue-stained squash mounts of stigmas of Annona cherimola showing germination of pollen from diploid A. cherimola, cv. Fino de Jete "Fj" (A), tetraploid (B), and triploid (C) hybrid. Scale bars, $100 \mu \mathrm{m}$. 
1986a) and Duguetia (Morawetz, 1984). Hexaploid and octoploid ploidy levels were also observed in the former genus Rollinia (Walker, 1972; Van Heusden, 1992) that is now included in the genus Annona (Rainer, 2007). In this work, this hexaploidy was also observed in Annona neosalicifolia previously named Rollinia neosalicifolia.

Although triploid mutants have been occasionally reported in Asimina triloba (Bowden, 1949), their presence is generally unknown in the tribe Annoneae. Interestingly, we observed a high percentage of triploid hybrid atemoyas (35\%) from an interspecific cross between $A$. cherimola $\times A$. squamosa. However, atemoya has been considered diploid (Bowden, 1948). The triploid hybrids may result from the fusion of reduced $(n)$ and unreduced $(2 n)$ gametes. The production of unreduced pollen grains is mainly controlled genetically (Mok et al., 1975; Ramsey and Schemske, 1998; Barcaccia et al., 2003; De Storme and Geelen, 2011; Mason and Pires, 2015), although there are several evidences, in many crop species, showing that the genes involved in the control of the unreduced pollen production are highly influenced by climatic conditions (Bretagnolle and Thompson, 1995; Ramsey and Schemske, 1998; Bretagnolle, 2001; De Storme et al., 2012). Studies in different species of Solanaceae, Salicaceae, Poaceae, Rosaceae, and Ranunculaceae have shown the influence of the environmental conditions, mainly light and temperature, in the production of $2 n$ gametes (Veilleux and Lauer, 1981; Hermsen, 1984; Felber, 1991; Fuzinatto et al., 2008; Rezaei et al., 2010; Pecrix et al., 2011; Guo L. et al., 2017). Particularly changes on temperatures prevailing at the gamete formation stage can cause various meiotic abnormalities due to the change in the expression of some genes that affect gamete viability (Kumar and Singhal, 2011; Singhal et al., 2011; Pecrix et al., 2011; Guo L. et al., 2017). A similar situation could be occurring in Annona in this work, where crosses were performed in a region with different temperature ranges than those present in the natural range of cultivation in the Neotropics during flowering time. While cherimoya is cultivated under an average annual temperature range of $18-21^{\circ} \mathrm{C}$ in Ecuador with limited annual fluctuations (Van Damme et al., 2000) or between a temperature range of $18^{\circ} \mathrm{C}$ and $25^{\circ} \mathrm{C}$ in the summer in Peru (Morton, 1987), under the growing conditions of Southern Spain, the fluctuation is higher with average high temperatures during the flowering season ranging from 19 to $29^{\circ} \mathrm{C}$ (Lora et al., 2011). Interestingly, this production of triploids is only observed in the progeny of the crosses made under these environmental conditions, since all the five accessions of atemoyas and the 338 accessions of A. cherimola maintained at the IHSM la Mayora Annona germplasm collection are diploids.

\section{DNA Amplification and Genotyping From Single Pollen Grains Revealed the Presence of Unreduced Pollen Grains}

Due to the small size of pollen and the difficulty of manipulation, DNA extraction from single pollen grains have been tried by laborious methods such germination of the pollen (Ziegenhagen et al., 1996; Honsho et al., 2016) and drilling into the pollen wall by using a UV-laser microbeam (Matsunaga et al., 1999). However, these methods are unsuitable for processing a large number of samples. In this work we optimized the approach of using single pollen grains through the application of multiplex PCR or co-amplification of several microsatellite markers in the same reaction (Ghislain et al., 2004; Meudt and Clarke, 2007; Guichoux et al., 2011) to amplify the haploid nuclear genome of a single pollen grain. The markers used in this work allowed us detect a high heterozygosity transmission level from the pollen donor plant to the progeny in which FDR seems to be involved. However, heterozygous markers for the male parent would be necessary to infer a possible SDR situation.

Triploids usually produce euploid gametes $(n, 2 n)$ (Belling and Blakeslee, 1922; Dermen, 1931; King, 1933; Satina and Blakeslee, 1937a,b; Lange and Wagenvoort, 1973; Dujardin and Hanna, 1988; Kovalsky et al., 2018) but also $3 n$ gametes through gamete non-reduction (Belling and Blakeslee, 1922; Lange and Wagenvoort, 1973; Mok et al., 1975). Thus, as described previously in other species, among the triploid interspecific hybrids between $A$. cherimola and A. squamosa we observed a frequency of $53 \%$ of pollen grains with one allele $(n), 41.3 \%$ with two alleles $(2 n)$ and $5.63 \%$ with three alleles $(3 n)$. It should be pointed out, however, that diploid pollen grains containing two copies of the same allele will be considered as haploids and, consequently, the number of $2 n$ pollen grains detected is the minimum, and the real number would be probably higher. As expected, a larger percentage of gametes with two alleles was observed in the triploid hybrids that showed approximately three times more unreduced gametes than diploids.

\section{Pollen Performance Was Affected in Unreduced Pollen}

DNA content can have a direct effect on pollen morphology and performance. Indeed, the examination of the size range of the pollen produced by an individual is the most common method to detect unreduced pollen. This method has been used as indicator of $2 n$ pollen presence in several species (Quinn et al., 1974; Ramanna, 1983; Sala et al., 1989; Orjeda et al., 1990; Bretagnolle, 2001; Crespel et al., 2006; Kovalsky and Solís Neffa, 2012; Nikoloudakis et al., 2018). In these studies, pollen grains with larger size have usually been considered as unreduced.

In this work, pollen grains showed larger diameters in triploid than in diploid genotypes. Size distribution of pollen grains revealed a relative overlap between unreduced and reduced pollen as described previously in other species (Maceira et al., 1993; Yan et al., 1997; Bretagnolle, 2001). Therefore, based on visual observations, we used a pollen grain size threshold with the mean size to determine the unreduced pollen grains produced in the parents and in each diploid and triploid genotype analyzed. A large variation was found in the production of unreduced pollen between triploid (38\%) and diploid (29\%) genotypes and a high positive correlation between the production of unreduced pollen grains and the ploidy level of the pollenproducing plant has been observed. However, some of the large pollen may not be $2 n$ (Maceira et al., 1993) and could include $3 n$ gametes. The frequency of unreduced gametes 
produced by the diploid interspecific hybrids was higher than that observed in other species such as Turnera sidoides (Kovalsky and Solís Neffa, 2012) or Anthoxanthum alpinum (Bretagnolle, 2001) with low frequency of unreduced pollen production ( $1 \%$ approximately) but, lower than those found in diploid population of Populus tomentosa with up to $50 \%$ of unreduced gametes (Zhang and Kang, 2010).

We also observed giant pollen grains with sizes higher than $75 \mu \mathrm{m}$ both in the diploid and triploid progeny, although it occurred more frequently in triploids. These giant pollen grains may be $3 n$ pollen (Tavoletti et al., 2000; Camadro et al., 2008; Zhang and Kang, 2010). The production of these $3 n$ gametes would increase the probability of obtaining tetraploid plants in the progeny obtained after crossing diploid and triploid genotypes.

Our data also revealed that some genotypes from the interspecific progeny seemed prone to produce a higher percentage of unreduced pollen than others. Similar patterns have been observed in other plant species (Watanabe and Peloquin, 1989; Haan et al., 1992; Maceira et al., 1992). The frequency of $2 n$ gametes was also found variable within the flowers of an individual tree in some cases such as in Medicago sativa (McCoy et al., 1982; Veilleux et al., 1982), Solanum spp. (Veilleux, 2011), and Turnera sidoides (Kovalsky and Solís Neffa, 2012, 2016). The capacity to produce $2 n$ gametes is governed by different alleles with different degrees of penetrance and expressivity (Bretagnolle and Thompson, 1995), and this could explain the individual variation observed within our population.

In addition to pollen size, pollen viability and germination could be affected by chromatin distribution imbalance in triploids (Bretagnolle and Thompson, 1995; Ramsey and Schemske, 1998). We observed a reduced pollen germination (7.7\%) in triploid compared to the diploid (58\%) genotypes. Reduction of pollen viability was reported in triploids of Manihot esculenta (cassava) (Nassar, 1992) and rose (Crespel et al., 2006) showing reductions of 19 and 50\%, respectively. However, in spite of the reduced pollen viability and germination, the evidence of the functionality of the pollen from triploid hybrid atemoyas was observed in the backcrosses. Similarly, functional pollen from triploids was also reported in potato (Mok et al., 1975; Tarn and Hawkes, 1986; Adiwilaga and Brown, 1991), and Lolium (Thomas et al., 1988) and, consequently, they could be used for introgression of genetic diversity from diploid to polyploid crop varieties (Bretagnolle and Thompson, 1995).

\section{Polyploidy, Evolurtion and Crop Improvement}

Recently, molecular tools have provided an interesting insight into the regulatory and genomic consequences of polyploidy. Together with the emerging evidence of ancestral duplication through polyploidization in model plants, knowledge of these consequences has stimulated thinking on the relationship between early polyploidy events, success of the polyploids, and the long-term fate of the new species (Comai, 2005). The " $2 n$ gametes pathway" is considered to be the main way of polyploidy origin and evolution in flowering plants (Harlan and deWet,
1975; Bretagnolle and Thompson, 1995; Ramsey and Schemske, 1998; De Storme and Geelen, 2013). Although unreduced pollen grain production has been observed in several species (Bretagnolle, 2001; Ramanna and Jacobsen, 2003; Taschetto and Pagliarini, 2003; Crespel et al., 2006; Gallo et al., 2007; Camadro et al., 2008; Zhang et al., 2009; Gómez-Rodríguez et al., 2012; Xue et al., 2011), the observations made in this work in two different species ( $A$. cherimola and $A$. squamosa) and their interspecific hybrids could have implications to explain the emergence of polyploidy and as valuable information for crop improvement in the Annonaceae. Additional work will be needed to explain the reasons behind the unexpected high production of polyploid genotypes in the interspecific and intraspecific crosses in Annona. In any case, polyploidy provides genome buffering, higher allelic diversity and the possibility of new functions for the duplicated genes; all this has important implications for crop improvement (Udall and Wendel, 2006; Mason, 2016) and, indeed, many of the current cropsr are hybrids of polyploids (Mason, 2016). Interestingly, most of the studies of polyploidy in crops have been performed in non-perennial species (Mason, 2016) and, consequently, there is a lack of information on the mechanisms and extension of polyploidy in most woody perennial crops, such as those studied in this work. The approaches shown here to study the reasons behind the unexpected high number of polyploids produced in intraspecific and interspecific crosses involving diploid genotypes can be useful to perform similar analyses in other woody perennial crops.

\section{AUTHOR CONTRIBUTIONS}

CM, MAV, and $\mathrm{JIH}$ conceived the study and designed the experiments. CM performed most of the experiments. JL performed some of the additional crosses, analyzed the progeny and the in vivo pollen germination experiments. CM, JL, MAV, and $\mathrm{JIH}$ wrote the manuscript.

\section{FUNDING}

This research was supported by Ministerio de Economía y Competitividad - European Regional Development Fund, European Union (AGL2016-77267-R, AGL2015-74071-JIN), the BBVA Foundation (BIOCON 08-184/09) and INIA (RFP201500009). CM was supported by a predoctoral grant of the Junta de Andalucía (AGR2742).

\section{ACKNOWLEDGMENTS}

We thank Sonia Civico for help with the karyotype and ploidy analyses and Yolanda Verdún for help with the molecular analyses. We would like to acknowledge the comments received by the two reviewers of the manuscript that have clearly helped to improve the paper from our initial submission. We also acknowledge support of the publication fee by the CSIC Open Access Publication Support Initiative through its Unit of Information Resources for Research (URICI). 


\section{REFERENCES}

Adams, K. L., and Wendel, J. F. (2005). Polyploidy and genome evolution in plants. Curr. Opin. Plant Biol. 8, 135-141. doi: 10.1016/j.pbi.2005.01.001

Adiwilaga, K. D., and Brown, C. R. (1991). Use of $2 \mathrm{n}$ pollen-producing triploid hybrids to introduce tetraploid Mexican wild species germ plasm to cultivated tetraploid potato gene pool. Theor. Appl. Genet. 81, 645-652. doi: 10.1007/ BF00226732

Ahmad, Q. N., Britten, E. J., and Byth, D. E. (1984). Effects of interacting genetic factors and temperature on meiosis and fertility in soybean $\times$ Glycine soja hybrids. Can. J. Genet. Cytol. 26, 50-56. doi: 10.1139/g84-009

Amborella Genome Project (2013). The Amborella genome and the evolution of flowering plants. Science 342:1241089. doi: 10.1126/science.1241089

Asana, J., and Adiata, R. (1945). The chromosome numbers in the family Annonaceae. Curr. Sci. 14, 74-75.

Bajpai, A., and Singh, A. K. (2006). Meiotic behavior of Carica papaya L.: spontaneous chromosome instability and elimination in important cvs. in north Indian conditions. Cytologia 71, 131-136. doi: 10.1508/cytologia.71.131

Barcaccia, G., Tavoletti, S., Mariani, A., and Veronesi, F. (2003). Occurrence, inheritance and use of reproductive mutants in alfalfa improvement. Euphytica 133, 37-56. doi: 10.1023/A:1025646523940

Belling, J., and Blakeslee, A. F. (1922). The assortment of chromosomes in triploid daturas. Am. Nat. 56, 339-346. doi: 10.1086/279873

Bennett, M., Bhandol, P., and Leitch, I. J. (2000). Nuclear DNA amounts in angiosperms and their modern uses -807 New Estimates. Ann. Bot. 86, 859-909. doi: 10.1006/anbo.2000.1253

Bowden, W. M. (1945). A List of chromosome numbers in higher plants. I. Acanthaceae to Myrtaceae. Am. J. Bot. 32, 81-92. doi: 10.2307/2437114

Bowden, W. M. (1948). Chromosome numbers in the Annonaceae. Am. J. Bot. 35, 377-381. doi: 10.1002/j.1537-2197.1948.tb08096.x

Bowden, W. M. (1949). Triploid mutants among diploid seedling populations of Asimina triloba. Bull. Torrey Bot. Club 76, 1-6.

Bradshaw, H. D., and Stettler, R. F. (1993). Molecular genetics of growth and development in Populus. I. Triploidy in hybrid poplars. Theor. Appl. Genet. 86-86, 301-307. doi: 10.1007/BF00222092

Bradshaw, J. E. (ed.). (2016). "Genome evolution and polyploidy," in Plant Breeding: Past, Present and Future, (Cham: Springer International Publishing), 233-269. doi: 10.1007/978-3-319-23285-0_8

Bretagnolle, F. (2001). Pollen production and spontaneous polyploidization in diploid populations of Anthoxanthum alpinum. Biol. J. Linn. Soc. 72, 241-247. doi: 10.1006/BIJL.2000.0489

Bretagnolle, F., and Thompson, J. D. (1995). Gametes with the somatic chromosome number: mechanisms of their formation and role in the evolution of autopolyploid plants. New Phytol. 129, 1-22. doi: 10.1111/j.1469-8137.1995. tb03005.x

Bringhurst, R., and Köhler, C. (1984). Breeding octoploid strawberries. Iowa State J. Res. 58, 371-381.

Brownfield, L., and Kohler, C. (2011). Unreduced gamete formation in plants: mechanisms and prospects. J. Exp. Bot. 62, 1659-1668. doi: 10.1093/jxb/erq371

Burley, J. (1965). Karyotype analysis of sitka spruce, Picea sitchensis (Bong.). Carr. Silvae Genet. 14, 127-132.

Camadro, E. L., Saffarano, S. K., Espinillo, J. C., Castro, M., and Simon, P. W. (2008). Cytological mechanisms of $2 \mathrm{n}$ pollen formation in the wild potato Solanum okadae and pollen-pistil relations with the cultivated potato, Solanum tuberosum. Genet. Resour. Crop Evol. 55, 471-477. doi: 10.1007/s10722-0079254- 1

Chamberlain, J. S., Pearlman, J. A., Muzny, D. M., Gibbs, R. A., Ranier, J. E., Caskey, C. T., et al. (1988). Expression of the murine Duchenne muscular dystrophy gene in muscle and brain. Science 239, 1416-1418. doi: 10.1126/science.3347839

Chatrou, L. W., Pirie, M. D., Erkens, R. H. J., Couvreur, T. L. P., Neubig, K. M., Abbott, J. R., et al. (2012). A new subfamilial and tribal classification of the pantropical flowering plant family Annonaceae informed by molecular phylogenetics. Bot. J. Linn. Soc. 169, 5-40. doi: 10.1111/j.1095-8339.2012. break01235.x doi: 10.1111/j.1095-8339.2012.01235.x

Comai, L. (2005). The advantages and disadvantages of being polyploid. Nat. Rev. Genet. 6, 836-846. doi: 10.1038/nrg1711

Couvreur, T. L. P., Pirie, M. D., Chatrou, L. W., Saunders, R. M. K., Su, Y. C. F., Richardson, J. E., et al. (2011). Early evolutionary history of the flowering plant family Annonaceae: steady diversification and boreotropical geodispersal. J. Biogeogr. 38, 664-680. doi: 10.1111/j.1365-2699.2010.02434.x

Crespel, L., Ricci, S. C., and Gudin, S. (2006). The production of $2 \mathrm{n}$ pollen in rose. Euphytica 151, 155-164. doi: 10.1007/s10681-006-9136-1

Cui, L., Wall, P. K., Leebens-Mack, J. H., Lindsay, B. G., Soltis, D. E., Doyle, J. J., et al. (2006). Widespread genome duplications throughout the history of flowering plants. Genome Res. 16, 738-749. doi: 10.1101/gr.4825606

Currier, H. B. (1957). Callose substance in plant cells. Am. J. Bot. 44, 478-488. doi: $10.2307 / 2438916$

Darlington, C. D. (1937). Recent Advances in Cytology, 2d Edn. Philadelphia, PA: P. Blakiston's Son \& Co., Inc. doi: 10.5962/bhl.title.6597

Darlington, C. D. (1965). Cytology. London: Reino Unido.

Darlington, C. D., and Ammal, E. K. J. (1945). Chromosome Atlas of Cultivated Plants. London: G. Allen \& Unwin ltd.

Datta, P. C., and De, B. (1990). Karyology of some Indian annonaceae. Cytologia 55, 187-196. doi: 10.1508/cytologia.55.187

De Rocher, E. J., Harkins, K. R., Galbraith, D. W., and Bohnert, H. J. (1990). Developmentally regulated systemic endopolyploid in succulents with small genomes. Science 250, 99-101. doi: 10.1126/science.250. 4977.99

De Storme, N., Copenhaver, G. P., and Geelen, D. (2012). Production of diploid male gametes in Arabidopsis by cold-induced destabilization of postmeiotic radial microtubule arrays. Plant Physiol. 160, 1808-1826. doi: 10.1104/pp.112. 208611

De Storme, N., and Geelen, D. (2011). The Arabidopsis mutant jason produces unreduced first division restitution male gametes through a parallel/fused spindle mechanism in meiosis II. Plant Physiol. 155, 1403-1415. doi: 10.1104/ pp. 110.170415

De Storme, N., and Geelen, D. (2013). Sexual polyploidization in plants cytological mechanisms and molecular regulation. New Phytol. 198, 670-684 doi: $10.1111 / \mathrm{nph} .12184$

Debodt, S., Maere, S., and Vandepeer, Y. (2005). Genome duplication and the origin of angiosperms. Trends Ecol. Evol. 20, 591-597. doi: 10.1016/j.tree.2005.07.008

Dermen, H. (1931). Polyploidy in Petunia. Am. J. Bot. 18, 250-261. doi: 10.2307/ 2435901

deWet, J. M. (1979). Origins of polyploids. Basic Life Sci. 13, 3-15.

Dewitte, A., Eeckhaut, T., Van Huylenbroeck, J., and Van Bockstaele, E. (2009). Occurrence of viable unreduced pollen in a Begonia collection. Euphytica 168, 81-94. doi: 10.1007/s10681-009-9891-x

Dewitte, A., Eeckhaut, T., Van Huylenbroeck, J., and Van Bockstaele, E. (2010). Meiotic aberrations during $2 \mathrm{n}$ pollen formation in Begonia. Heredity 104 215-223. doi: 10.1038/hdy.2009.111

Dolezel, J., and Bartos, J. (2005). Plant DNA flow cytometry and estimation of nuclear genome size. Ann. Bot. 95, 99-110. doi: 10.1093/aob/mci005

Doležel, J., Binarová, P., and Lcretti, S. (1989). Analysis of nuclear DNA content in plant cells by flow cytometry. Biol. Plant. 31, 113-120. doi: 10.1007/BF02907241

Dujardin, M., and Hanna, W. W. (1988). Cytology and breeding behavior of a partially fertile triploid pearl millet. J. Hered. 79, 216-218. doi: 10.1093/ oxfordjournals.jhered.a110499

Esen, A., and Soost, R. K. (1971). Unexpected triploids in citrus: their origin, identification, and possible use. J. Hered. 62, 329-333. doi: 10.1093/ oxfordjournals.jhered.a108186

Felber, F. (1991). Establishment of a tetraploid cytotype in a diploid population: effect of relative fitness of the cytotypes. J. Evol. Biol. 4, 195-207. doi: 10.1046/j. 1420-9101.1991.4020195.x

Felber, F., and Bever, J. D. (1997). Effect of triploid fitness on the coexistence of diploids and tetraploids. Biol. J. Linn. Soc. 60, 95-106. doi: 10.1006/BIJL.1996. 0090

Folorunso, A. E., and Olorode, O. (2008). Karyotype studies in some species of the family annonaceae. Ife J. Sci. 9, 161-166. doi: 10.4314/ijs.v9i2.32244

Fuzinatto, V. A., Pagliarini, M. S., and Valle, C. B. (2008). Evaluation of microsporogenesis in an interspecific Brachiaria hybrid (Poaceae) collected in distinct years. Genet. Mol. Res. 7, 424-432. doi: 10.4238/vol7-2gmr430

Gallo, P. H., Micheletti, P. L., Boldrini, K. R., Risso-Pascotto, C., Pagliarini, M. S., and do Valle, C. B. (2007). 2n Gamete formation in the genus Brachiaria (Poaceae: Paniceae). Euphytica 154, 255-260. doi: 10.1007/s10681-006-9294-1

Ghislain, M., Spooner, D. M., Vásquez, C., Waugh, R., Bonierbale, M., Rodríguez, F., et al. (2004). Selection of highly informative and user-friendly 
microsatellites (SSRs) for genotyping of cultivated potato. Theor. Appl. Genet. 108, 881-890. doi: 10.1007/s00122-003-1494-7

Gómez-Rodríguez, V. M., Rodríguez-Garay, B., and Barba-Gonzalez, R. (2012). Meiotic restitution mechanisms involved in the formation of $2 n$ pollen in Agave tequilana Weber and Agave angustifolia Haw. Springerplus 1:17. doi: 10.1186/ 2193-1801-1-17

Gottsberger, G. (1999). Pollination and evolution in neotropical Annonaceae. Plant Species Biol. 14, 143-152. doi: 10.1007/s10886-012-0173-z

Grant, V. (1963). The Origin of Adaptations. New York, NY: Columbia University Press.

Guichoux, E., Lagache, L., Wagner, S., Chaumeil, P., Léger, P., Lepais, O., et al. (2011). Current trends in microsatellite genotyping. Mol. Ecol. Resour. 11, 591-611. doi: 10.1111/j.1755-0998.2011.03014.x

Guo, L., Xu, W., Zhang, Y., Zhang, J., and Wei, Z. (2017). Inducing triploids and tetraploids with high temperatures in Populus sect. Tacamahaca. Plant Cell Rep. 36, 313-326. doi: 10.1007/s00299-016-2081-0

Guo, X., Tang, C. C., Thomas, D. C., Couvreur, T. L. P., and Saunders, R. M. K. (2017). A mega-phylogeny of the Annonaceae: taxonomic placement of five enigmatic genera and recognition of a new tribe, Phoenicantheae. Sci. Rep. 7:7323. doi: 10.1038/s41598-017-07252-2

Haan, A. D., Maceira, N. O., Lumaret, R., and Delay, J. (1992). Production of $2 \mathrm{n}$ gametes in diploid subspecies of Dactylis glomerata L. 2. Occurrence and frequency of 2 n eggs. Ann. Bot. 69, 345-350. doi: 10.1093/oxfordjournals.aob. a088351

Harlan, J. R., and deWet, J. M. J. (1975). On Ö. Winge and a prayer: the origins of polyploidy. Bot. Rev. 41, 361-390. doi: 10.1007/BF02860830

Hermsen, J. G. (1984). Mechanisms and genetic implications of 2n-gamete formation. Iowa State J. Res. 58, 421-434.

Honsho, C., Sakata, A., Tanaka, H., Ishimura, S., and Tetsumura, T. (2016). Singlepollen genotyping to estimate mode of unreduced pollen formation in Citrus tamurana cv. Nishiuchi Konatsu. Plant Reprod. 29, 189-197. doi: 10.1007/ s00497-016-0277-7

Isagi, Y., and Suyama, Y. (2011). Single-Pollen Genotyping. New York, NY: Springer. doi: 10.1007/978-4-431-53901-8

Iwanaga, M., Freyre, R., and Orjeda, G. (1991). Use of Ipomoea trifida (HBK.) G. Don germ plasm for sweet potato improvement. 1. Development of synthetic hexaploids of $<$ I $>$ I. trifida by ploidy-level manipulations. Genome 34, 201-208. doi: 10.1139/g91-032

Jaillon, O., Aury, J. M., Noel, B., Policriti, A., Clepet, C., Casagrande, A., et al. (2007). The grapevine genome sequence suggests ancestral hexaploidization in major angiosperm phyla. Nature 449, 463-467. doi: 10.1038/nature06148

Johnson, D. M. (1989). Revision of Disepalum (Annonaceae). Brittonia 41, 356-378. doi: 10.2307/2807547

Karpechenko, G. D. (2010). The production of polyploid gametes in hybrids. Hereditas 9, 349-368. doi: 10.1111/j.1601-5223.1927.tb03536.x

King, E. (1933). Chromosome behavior in a triploid Tradescantia. J. Hered. 24, 253-256. doi: 10.1093/oxfordjournals.jhered.a103793

Kovalsky, I. E., Roggero Luque, J. M., Elías, G., Fernández, S. A., and Solís Neffa, V. G. (2018). The role of triploids in the origin and evolution of polyploids of Turnera sidoides complex (Passifloraceae, Turneroideae). J. Plant Res. 131, 77-89. doi: 10.1007/s10265-017-0974-9

Kovalsky, I. E., and Solís Neffa, V. G. (2012). Evidence of 2n microspore production in a natural diploid population of Turnera sidoides subsp. carnea and its relevance in the evolution of the $T$. sidoides (Turneraceae) autopolyploid complex. J. Plant Res. 125, 725-734. doi: 10.1007/s10265-012-0493-7

Kovalsky, I. E., and Solís Neffa, V. G. (2016). Evidence of the production of $2 \mathrm{n}$ eggs in diploid plants of the autopolyploid complex Turnera sidoides L. (Passifloraceae). Plant Syst. Evol. 302, 357-366. doi: 10.1007/s00606-0151268-0

Kreiner, J., Kron, P., and Husband, B. (2017). Evolutionary dynamics of unreduced gametes. Trends Genet. 33, 583-593. doi: 10.1016/j.tig.2017.06.009

Kumar, L. S. S., and Ranadive, K. (1941). A cytological study of the genus Annona. J. Univ. Bombay 10B, 1-8. doi: 10.3732/ajb.1400312

Kumar, P., and Singhal, V. K. (2011). Male meiosis, morphometric analysis and distribution pattern of $2 \times$ and $4 \times$ cytotypes of Ranunculus hirtellus Royle, 1834 (Ranunculaceae) from the cold regions of northwest Himalayas (India). Comp. Cytogenet. 5, 143-161. doi: 10.3897/CompCytogen.v5i3. 1359
Lange, W., and Wagenvoort, M. (1973). Meiosis in triploid Solanum tuberosum L. Euphytica 22, 8-18. doi: 10.1007/BF00021550

Larranaga, N., Albertazzi, F. J., and Hormaza, J. I. (2019). Phylogenetics of Annona cherimola (Annonaceae) and some of its closest relatives. J. Syst. Evol. (in press). doi: 10.1111/jse.12473 [Epub ahead of print].

Leeton, P., and Fripp, Y. (1991). Breeding system, karyotype and variation within and between populations of Rutidosis leptorrhynchoides F Muell (Asteraceae, Inuleae). Aust. J. Bot. 39, 85-96. doi: 10.1071/BT9910085

Li, B.-H., Xu, X.-M., and Ridout, M. S. (2004). Modelling the establishment and spread of autotetraploid plants in a spatially heterogeneous environment. J. Evol. Biol. 17, 562-573. doi: 10.1111/j.1420-9101.2004.00700.x

Lim, K.-B., Ramanna, M. S., de Jong, J. H., Jacobsen, E., and van Tuyl, J. M. (2001). Indeterminate meiotic restitution (IMR): a novel type of meiotic nuclear restitution mechanism detected in interspecific lily hybrids by GISH. Theor. Appl. Genet. 103, 219-230. doi: 10.1007/s001220100638

Linskens, H., and Esser, K. (1957). Uber eine spezifische anfarbung der pollenschlauche im griffel und die zahl der kallosepfropfen nach selbstung und fremdung. Naturwiss 44, 16-17. doi: 10.1007/BF00629340

Lora, J., de Oteyza, M. A. P., Fuentetaja, P., and Hormaza, J. I. (2006). Low temperature storage and in vitro germination of cherimoya (Annona cherimola Mill.) pollen. Sci. Hortic. 108, 91-94. doi: 10.1016/j.scienta.2005.12.003

Lora, J., Herrero, M., and Hormaza, J. I. (2011). Stigmatic receptivity in a dichogamous early-divergent angiosperm species, Annona cherimola (Annonaceae): influence of temperature and humidity. Am. J. Bot. 98, 265-274. doi: $10.3732 /$ ajb. 1000185

Lora, J., Herrero, M., and Hormaza, J. I. (2012). Pollen performance, cell number, and physiological state in the early-divergent angiosperm Annona cherimola Mill. (Annonaceae) are related to environmental conditions during the final stages of pollen development. Sex. Plant Reprod. 25, 157-167. doi: 10.1007/ s00497-012-0187-2

Lora, J., Herrero, M., and Hormaza, J. I. (2014). Microspore development in Annona (Annonaceae): differences between monad and tetrad pollen. Am. J. Bot. 101, 1508-1518. doi: 10.3732/ajb.1400312

Lora, J., Testillano, P. S. S., Risueño, M. C., Hormaza, J. I. I., Herrero, M., Risueno, M. C., et al. (2009). Pollen development in Annona cherimola Mill. (Annonaceae). Implications for the evolution of aggregated pollen. BMC Plant Biol. 9:129. doi: 10.1186/1471-2229-9-129

Losada, J. M., Hormaza, J. I., and Lora, J. (2017). Pollen-pistil interaction in pawpaw (Asimina triloba), the northernmost species of the mainly tropical family Annonaceae. Am. J. Bot. 104, 1891-1903. doi: 10.3732/ajb.1700319

Maceira, N. O., Haan, A. A. D. E., Lumaret, R., Billon, M., and Delay, J. (1992). Production of $2 \mathrm{n}$ gametes in diploid subspecies of Dactylis glomerata L. 1. Occurrence and frequency of 2 n pollen. Ann. Bot. 69, 335-343.

Maceira, N. O., Jacquard, P., and Lumaret, R. (1993). Competition between diploid and derivative autotetraploid Dactylis glomerata L. from Galicia. Implications for the establishment of novel polyploid populations. New Phytol. 124, 321-328. doi: 10.1111/j.1469-8137.1993.tb03822.x

Martin, C. (2013). Desarrollo de un Mapa Genético, Variación de Ploidía y Anomalías Meióticas en el Género Annona. Ph.D. thesis. University of Malaga, Málaga.

Mason, A. S. (2016). Polyploidy and Hybridization for Crop Improvement, ed. A. S. Mason (Boca Raton, FL: Taylor \& Francis Group). doi: 10.1201/9781315369259

Mason, A. S., and Pires, J. C. (2015). Unreduced gametes: meiotic mishap or evolutionary mechanism? Trends Genet. 31, 5-10. doi: 10.1016/J.TIG.2014. 09.011

Matsunaga, S., Schutze, K., Donnison, I. S., Grant, S. R., Kuroiwa, T., and Kawano, S. (1999). Single pollen typing combined with laser-mediated manipulation. Plant J. 20, 371-378. doi: 10.1046/j.1365-313X.1999. 00612.x

McCoy, T. J., Phillips, R. L., and Rines, H. W. (1982). Cytogenetic analysis of plants regenerated from oat (Avena sativa) tissue cultures; high frequency of partial chromosome loss. Can. J. Genet. Cytol. 24, 37-50. doi: 10.1139/g82-005

Meudt, H. M., and Clarke, A. C. (2007). Almost forgotten or latest practice? AFLP applications, analyses and advances. Trends Plant Sci. 12, 106-117. doi: 10.1016/j.tplants.2007.02.001

Miege, J. (1960). Nombres chromosomiques de plants D'Afrique occidentale. Rev. Cytol. Biol. Veget. 21, 373-384. 
Mok, D. W. S., Peloquin, S. J., and Tarn, T. R. (1975). Cytology of potato triploids producing 2 N pollen. Am. Potato J. 52, 171-174. doi: 10.1007/BF02838107

Morawetz, W. (1984). Karyological races and ecology of the Brazilian Duguetia furfuracea as compared with Xylopia aromatica (Annonaceae). Flora 175, 195-209. doi: 10.1016/S0367-2530(17)31434-2

Morawetz, W. (1986a). Remarks on karyological differentiation patterns in tropical woody plants. Plant Syst. Evol. 152, 49-100. doi: 10.1007/BF009 85351

Morawetz, W. (1986b). Systematics and karyoevolution in Magnoliidae: Tetrameranthus as compared with other Annonaceae genera of the same chromosome number. Plant Syst. Evol. 154, 147-173. doi: 10.1007/BF00984875

Morawetz, W. (1988). Karyosystematics and evolution of Australian Annonaceae as compared with Eupomatiaceae, Himantandraceae, and Austrobaileyaceae. Plant Syst. Evol. 159, 49-79. doi: 10.1007/BF00937425

Morton, J. (1987). "Cherimoya," in Fruits of Warm Climates, ed. C. F. Dowling (Miami, FL: J.F. Morton), 65-69.

Nassar, N. M. A. (1992). Production of triploid cassava, Manihot esculenta Crantz by hybrid diploid gametes. Field Crops Res. 30, 173-182. doi: 10.1016/03784290(92)90066-I

Negri, V., and Veronesi, F. (1989). Evidence for the existence of 2n gametes in Lotus tenuis Wald. et Kit. $(2 \mathrm{n}=2 \mathrm{x}=12)$ : their relevance in evolution and breeding of Lotus corniculatus L. $(2 \mathrm{n}=4 \mathrm{x}=24)$. Theor. Appl. Genet. 78, 400-404. doi: $10.1007 /$ BF00265303

Nikoloudakis, N., Aissat, A., and Katsiotis, A. (2018). Screening A. ventricosa populations for 2n gametes. Euphytica 214:34. doi: 10.1007/s10681-017-2107-x

Okada, H., and Ueda, K. (1984). Cytotaxonomical studies on Asian Annonaceae. Plant Syst. Evol. 144, 165-177. doi: 10.1007/BF00984131

Orjeda, G., Freyre, R., and Iwanaga, M. (1990). Production of 2n pollen in diploid Ipomoea trifida, a putative wild ancestor of sweet potato. J. Hered. 81, 462-467. doi: 10.1093/oxfordjournals.jhered.a111026

Otto, S. P., and Whitton, J. (2000). Polyploid incidence and evolution. Annu. Rev. Genet. 34, 401-437. doi: 10.1146/annurev.genet.34.1.401

Ozaki, Y., Takeuchi, Y., Iwato, M., Sakazono, S., and Okubo, H. (2014). Occurrence of a spontaneous triploid progeny from crosses between diploid asparagus (Asparagus officinalis L.) plants and its origin determined by SSR markers. J. Jpn. Soc. Hortic. Sci. 83, 290-294. doi: 10.2503/jishs1.CH- 073

Parre, E., and Geitmann, A. (2005). Pectin and the role of the physical properties of the cell wall in pollen tube growth of Solanum chacoense. Planta 220, 582-592. doi: 10.1007/s00425-004-1368-5

Pecrix, Y., Rallo, G., Folzer, H., Cigna, M., Gudin, S., and Le Bris, M. (2011). Polyploidization mechanisms: temperature environment can induce diploid gamete formation in Rosa sp. J. Exp. Bot. 62, 3587-3597. doi: 10.1093/jxb/err052

Perveen, A., and Qaiser, M. (2001). Pollen flora of Pakistan: 27. Turk. J. Bot. 25, $385-388$.

Pomper, K. W., and Layne, D. R. (2010). “The North American pawpaw: botany and horticulture," in Horticultural Reviews, ed. J. Janick (Oxford: John Wiley \& Sons, Inc), 349-382. doi: 10.1002/9780470650882.ch7

Popenoe, H. (1989). Lost Crops of the Incas: Little known Plants of the Andes with Promise of Worldwide Cultivation, ed. National Research Center (Washington DC: National Academy Press).

Quinn, A. A., Mok, D. W. S., and Peloquin, S. J. (1974). Distribution and significance of diplandroids among the diploid solanums. Am. Potato J. 51, 16-21. doi: 10.1007/BF02852024

Rainer, H. (2007). Monographic studies in the genus Annona L. (Annonaceae): inclusion of the genus Rollinia A.St. Hil. Ann. Nat. Mus. Wien Ser. B Bot. Zool. 108, 191-205.

Ramanna, M. S. (1983). First division restitution gametes through fertile desynaptic mutants of potato. Euphytica 32, 337-350. doi: 10.1007/BF00021442

Ramanna, M. S., and Jacobsen, E. (2003). Relevance of sexual polyploidization for crop improvement - A review. Euphytica 133, 3-8. doi: 10.1023/A: 1025600824483

Ramsey, J., and Schemske, D. W. (1998). Pathways, mechanisms, and rates of polyploids formation in flowering plants. Annu. Rev. Ecol. Syst. 29, 467-501. doi: 10.1146/annurev.ecolsys.29.1.467

Rezaei, M., Arzani, A., and Sayed-Tabatabaei, B. E. (2010). Meiotic behaviour of tetraploid wheats (Triticum turgidum L.) and their synthetic hexaploid wheat derivates influenced by meiotic restitution and heat stress. J. Genet. 89, 401-407. doi: 10.1007/s12041-010-0058-2
Rosell, P., Herrero, M., and Sauco, V. G. (1999). Pollen germination of cherimoya (Annona cherimola Mill.). In vivo characterization and optimization of in vitro germination. Sci. Hortic. 81, 251-265. doi: 10.1016/S0304-4238(99)00012-6

Saini, H. S. (1997). Effects of water stress on male gametophyte development in plants. Sex. Plant Reprod. 10, 67-73. doi: 10.1007/s004970050069

Sala, C. A., Camadro, E. L., Salaberry, M. T., and Mendiburu, A. O. (1989). Cytological mechanism of $2 \mathrm{n}$ pollen formation and unilateral sexual polyploidization in Lolium. Euphytica 43, 1-6. doi: 10.1007/BF00037889

Santos, R. P. D., and Mariath, J. E. D. A. (1999). Storage substances in the androgametogenesis and mature pollen grain of Ilex paraguariensis St. Hil. (Aquifoliaceae). Rev. Bras. Bot. 22, 125-131. doi: 10.1590/S010084041999000200003

Sarkissian, T. S., and Harder, L. D. (2001). Direct and indirect responses to selection on pollen size in Brassica rapa L. J. Evol. Biol. 14, 456-468. doi: 10.1046/j.14209101.2001.00285.x

Satina, S., and Blakeslee, A. F. (1937a). Chromosome behavior in triploid Datura. II. The female gametophyte. Am. J. Bot. 24, 621-627. doi: 10.2307/2436643

Satina, S., and Blakeslee, A. F. (1937b). Chromosome behavior in triploids of Datura stramonium. I. The male gametophyte. Am. J. Bot. 24, 518-527. doi: $10.2307 / 2437074$

Sattler, M. C., Carvalho, C. R., and Clarindo, W. R. (2016). The polyploidy and its key role in plant breeding. Planta 243, 281-296. doi: 10.1007/s00425-015$2450-\mathrm{x}$

Sauer, W., and Ehrendorfer, F. (1984). Notes on the karyosystematics of Annonaceae. Plant Syst. Evol. 146, 47-55. doi: 10.1007/BF00984053

Singhal, K. V., Rana, P. K., and Kumar, P. (2011). Syncytes during male meiosis resulting in $2 \mathrm{n}$ pollen grain formation in Lindelofia longiflora var. falconeri. J. Syst. Evol. 49, 406-410. doi: 10.1111/j.1759-6831.2011.00144.x

Soltis, D. E., Albert, V. A., Leebens-Mack, J., Bell, C. D., Paterson, A. H., Zheng, C., et al. (2009). Polyploidy and angiosperm diversification. Am. J. Bot. 96, 336-348. doi: 10.3732/ajb.0800079

Sun, K., Hunt, K., and Hauser, B. A. (2004). Ovule abortion in Arabidopsis triggered by stress. Plant Physiol. 135, 2358-2367. doi: 10.1104/pp.104.043091

Tanaka, R., and Okada, H. (1972). Karyological studies in four species of Annonaceae, a primitive angiosperm. J. Sci. Hiroshima Univ. Ser. B Div 2, 85-105.

Tarn, T. R., and Hawkes, J. G. (1986). Cytogenetic studies and the occurrence of triploidy in the wild potato species Solanum commersonii Dun. Euphytica 35, 293-302. doi: 10.1007/BF00028567

Taschetto, O. M., and Pagliarini, M. S. (2003). Occurrence of 2n and jumbo pollen in the Brazilian ginseng (Pfaffia glomerata and P. tuberosa). Euphytica 133, 139-145. doi: 10.1023/A:1025683511162

Tavoletti, S., Pesaresi, P., Barcaccia, G., Albertini, E., and Veronesi, F. (2000). Mapping the jp (jumbo pollen) gene and QTLs involved in multinucleate microspore formation in diploid alfalfa. Theor. Appl. Genet. 101, 372-378. doi: $10.1007 / \mathrm{s} 001220051493$

Thakur, D., and Singh, R. (1969). Karyomorphological studies in some Annona species. Indian J. Genet. Plant Breed. 29, 285-290.

Thakur, D. R., and Singh, R. N. (1965). Meiosis in Annona. Indian J. Genet. Plant Breed. 25, 367-371.

The Angiosperm Phylogeny Group, Chase, M. W., Christenhusz, M. J. M., Fay, M. F., Byng, J. W., Judd, W. S., et al. (2016). An update of the angiosperm phylogeny group classification for the orders and families of flowering plants: APG IV. Bot. J. Linn. Soc. 181, 1-20. doi: 10.1111/boj. 12385

Thomas, H., Morgan, W. G., and Humphreys, M. W. (1988). The use of a triploid hybrid for introgression in Lolium species. Theor. Appl. Genet. 76, 299-304. doi: 10.1007/BF00257859

Udall, J. A., and Wendel, J. F. (2006). Polyploidy and crop improvement. Crop Sci. 46(Suppl._1), 3-14. doi: 10.2135/cropsci2006.07.0489tpg

Ureshino, K., and Miyajima, I. (2002). The study on the relationship between leaf colors and ptDNA inheritance in intersectional cross of Rhododendron kiusianum $\times$ R. japonicum $f$. flavum, resulting in an unexpected triploid progeny. Engei Gakkai Zasshi 71, 214-219. doi: 10.2503/jjshs. 71.214

Van Damme, P., Van Damme, V., and Scheldeman, X. (2000). Ecology and cropping of cherimoya (Annona cherimola Mill.) in Latin America. New Data from Ecuador. Fruits 55, 195-256. 
Van de Peer, Y., Mizrachi, E., and Marchal, K. (2017). The evolutionary significance of polyploidy. Nat. Rev. Genet. 18, 411-424. doi: 10.1038/nrg.2017.26

Van Heusden, E. C. H. (1992). Flowers of Annonaceae: morphology, classification, and evolution. Blumea Suppl. 7, 1-218.

Veilleux, R. (2011). "Diploid and polyploid gametes in crop plants: mechanisms of formation and utilization in plant breeding," in Plant Breeding Reviews, ed. J. Janick (Hoboken, NJ: John Wiley \& Sons, Inc), 253-288. doi: 10.1002/ 9781118061008.ch6

Veilleux, R. E., and Lauer, F. I. (1981). Variation for 2n pollen production in clones of Solanum phureja Juz. and Buk. Theor. Appl. Genet. 59, 95-100. doi: 10.1007/BF00285897

Veilleux, R. E., McHale, N. A., and Lauer, F. I. (1982). 2n gametes in diploid Solanum: frequency and types of spindle abnormalities. Can. J. Genet. Cytol. 24, 301-314. doi: 10.1139/g82-032

Viccini, L. F., and De Carvalho, C. R. (2002). Meiotic chromosomal variation resulting from irradiation of pollen in maize. J. Appl. Genet. 43, 463-469.

Walker, J. W. (1972). Chromosome numbers, phylogeny, phytogeography of the Annonaceae and their bearing on the (original) basic chromosome number of angiosperms. Taxon 21, 57-65.

Wang, J., Li, D., Shang, F., and Kang, X. (2017). High temperature-induced production of unreduced pollen and its cytological effects in Populus. Sci. Rep. 7:5281. doi: 10.1038/s41598-017-05661-x

Watanabe, K., and Peloquin, S. J. (1989). Occurrence of 2n pollen and ps gene frequencies in cultivated groups and their related wild species in tuber-bearing Solanums. Theor. Appl. Genet. 78, 329-336. doi: 10.1007/BF00265292

Wester, P. J. (1910). Pollination experiments with Anonas. Bull. Torrey Bot. Club 37, 529-539. doi: $10.2307 / 2479045$

Xue, Z., Liu, P., and Liu, M. (2011). Cytological mechanism of 2n pollen formation in Chinese jujube (Ziziphus jujuba Mill. 'Linglingzao'). Euphytica 182, 231-238. doi: 10.1007/s10681-011-0461-7
Yan, G., Ferguson, A. R., McNeilage, M. A., and Murray, B. G. (1997). Numerically unreduced (2n) gametes and sexual polyploidization in Actinidia. Euphytica 96, 267-272. doi: 10.1023/A:1003037920247

Younis, A., Hwang, Y.-J., and Lim, K.-B. (2014). Exploitation of induced 2ngametes for plant breeding. Plant Cell Rep. 33, 215-223. doi: 10.1007/s00299013-1534-y

Zhang, J.-F., Wei, Z.-Z., Li, D., and Li, B. (2009). Using SSR markers to study the mechanism of $2 \mathrm{n}$ pollen formation in Populus $\times$ euramericana (Dode) Guinier and P. × popularis. Ann. For. Sci. 66, 506-506. doi: 10.1051/forest/2009032

Zhang, Z., and Kang, X. (2010). Cytological characteristics of numerically unreduced pollen production in Populus tomentosa Carr. Euphytica 173, 151159. doi: 10.1007/s10681-009-0051-0

Ziegenhagen, B., Schuerte, M., Kormutak, A., and Scholz, F. (1996). Plastid DNA polymorphism of megagametophytes and pollen in two Abies species. Silvae Genet. 45, 355-358.

Conflict of Interest Statement: CM is currently employed by company Rijk Zwaan Ibérica S.A.

The remaining authors declare that the research was conducted in the absence of any commercial or financial relationships that could be construed as a potential conflict of interest.

Copyright $\odot 2019$ Martin, Viruel, Lora and Hormaza. This is an open-access article distributed under the terms of the Creative Commons Attribution License (CC BY). The use, distribution or reproduction in other forums is permitted, provided the original author(s) and the copyright owner(s) are credited and that the original publication in this journal is cited, in accordance with accepted academic practice. No use, distribution or reproduction is permitted which does not comply with these terms. 